\title{
Characterisation and Grading of Four Selected Timber Species Grown in Nigeria in Accordance with Bs 5268
}

\author{
U.N. Wilson ${ }^{1 *}$, Y.N. Mohammad ${ }^{2}$, I.S. Mohammed ${ }^{3}$, F.O. Adeyemi ${ }^{4}$ \\ ${ }^{1,2,3}$ Department of Civil Engineering, Nigerian Defence Academy, Kaduna, NIGERIA. \\ ${ }^{4}$ Department of Civil Engineering, Ajayi Crowther University, Oyo, NIGERIA.
}

\begin{abstract}
This study presents a development of strength classes for Vitex doniana, Diospyros mespliformis, Parkia biglobosa and Isoberlinia doka, northern Nigeria timber species in accordance with BS 5268-2 (2002) and NCP 2(1973). The specimens for the experimental measurements were obtained from timber-sheds in Zaria, Kaduna - Northern part of Nigeria. The laboratory experiments were conducted to determine the physical and mechanical properties of the selected timber species. The specimens were prepared in accordance with BS 373 for small clear specimens for the determination of physical and mechanical properties. Flexural streng th properties were determined using three point bending test. Adjustment was made on the mechanical properties at moisture content of $12 \%$ and $18 \%$ in conformity with BS 5268-2 (2002) and NCP2 (1973) respectively. The laboratory data were analyzed using data analysis tool pack in Microsoft excel 2019 to generate the mean, coefficients of variation and theoretical distribution models which form the uncertainty models. Basic and grade stresses were also computed using experimental failure stresses. The selected timber species were then classified using the grade bending stress, density and mean modulus of elasticity obtained. Vitex doniana, Diospyros mespliformis, Parkia biglobosa and Isoberlinia doka were assigned to strength classes D30, D40, C40 and D30 in accordance with BS 5268-2 (2002) respectively. Similarly, in accordance with the NCP 2 (1973), these species belong to N4, N3, $N 4$ and N3 respectively. The results obtained show that Vitex doniana, Diospyros mespliformis and Isoberlinia doka are hardwoods whereas, only Parkia biglobosa is a softwood specie.
\end{abstract}

Keywords: ANOVA, Characterisation, Dinya, Doka, Dorowa, Grading, Kanya, Mechanical properties, Physical properties.

\subsection{INTRODUCTION}

To appraise any structure intelligently, the construction material characteristics need to be understood. This as a general fact, becomes necessary for timber which is an organic material with a complex structure. Timber characteristics are better understood by first looking at its source, the tree, as it grows to maturity [1]. It has been in use for centuries for various construction purposes such as in bridges, buildings and furniture industries [2]. As a naturally occurring organic material, the knowledge of its behaviour through research and improved technology has led to efficient, safe and more challenging and exciting applications in our modern world [3]. Nigeria being blessed with timber in abundance stands to derive immense opportunities from its proper utilization.

Timber has many unique attributes. It has a heat texture and eye-catching look and it is frequently used for inside finishing as well as building of main structure. It is effortless to work with and can be produced in an

*Corresponding author (Tel: +234 (0) 806984 9262)

Email addresses: unwilson@nda.edu.ng (U.N.

Wilson), yahyanma@gmail.com (Y.N. Mohammad),

festusade4@yahoo.com (F.O. Adeyemi),

isanimoh@gmail.com (I.S. Mohammed). extensive range of shapes and sizes.

Timber has a high strength-to-weight ratio and has specific thermal insulation properties. Timber can be used compositely with concrete and steel. It is the only constructing material that negligibly contributes to greenhouse emissions and it is absolutely renewable and largely recyclable material [3]. Wood acts as a carbon sink and has low embodied energy [4]. The energy needed to convert trees into wood and hence into structural timber is significantly less than that required by steel and concrete. Furthermore, it does not corrode which could result in loss of thickness as in steel or as in exposed concrete reinforcement [5].

Because it is a naturally grown material, timber is a complex building material. Its properties are generally unpredictable and are sensitive to environmental and loading conditions. It is highly anisotropic material with excessive strength and stiffness parallel to the grain on one hand but low properties perpendicular to the grain. These factors have to be taken into account in the design of timber structures [3].

There are thousands of tree species on the planet which can be narrowed down to two main categories: Softwoods and Hardwoods with each of the group having characteristics that define them. Softwood is the timber of 
a conifer whereas hardwood is that of a deciduous tree. Softwood and hardwood are botanical terms and do not necessarily refer to the density or hardness of the wood. Though most hardwoods have a higher density than most softwoods, some softwoods can be quite hard and some hardwood can be quite soft [5].

Unlike other building materials such as steel and concrete, timber properties are not designed or produced by means of some recipe but may be required to fulfill certain requirements by quality control procedure referred to as grading [6]. Certain timber material properties like strength and stiffness are of special importance for design of load bearing elements in buildings. Form, appearance and moisture content are equally of no less important requirement [5]. Classification of timber species of similar properties into the same group is referred to as grading. This procedure enables timber to meet either visual appearance or strength or both requirements.

Timbers are classified based on their reference material properties (density, modulus of elasticity and bending strength) that are obtained from laboratory experiments. Generally, strength grading offers several advantages both to the designer and the supplier of timber. The designer can undertake his design without the need to check on the availability and price of a large number of species and grades which could be used. Timbers can be supplied in any of the species or grade combinations that meet the strength class in a specification. The concept also allows new species to be introduced into the market without affecting existing specifications for timber. In summary, the allocation of species to a strength class allows engineers to use the most suitable selection of the material for a particular purpose.

Characterization and grading of timber species for engineering applications have been very limited in Nigeria [4]. Most of the wood materials found in Kaduna are supplied from the Southern part of the country.
Only few species exist for commercial purposes out of the myriads of species naturally available [7]. Classifying and grading the lesser utilized grown trees will help in reducing over-exploitation of the few commercial species such as Mahogany, 'Obeche' and 'Teak' whose properties have been established.

This research work hereby examines the properties of the following timber species for characterization and grading; Vitex doniana, Diospyros mespiliformis, Parkia biglobosa and Isoberlinia doka.

\subsection{Background of Study}

Wood as material that grows naturally, has different properties through its organic nature. This varies from one specie to another, and within the same specie variation exists. Wood behaves as an anisotropic and hygroscopic material with a structure that is heterogeneous. A tree characteristic depends on several factors; growth location, quantity and quality of water, quality of soil it grows on and other environmental influences. Hence the reason why timber properties are always expressed as average and not exact values.

\subsection{MATERIALS AND METHODS}

Timbers used for this research were locally sourced from North-Western Nigeria. These species have been in use in this part of Nigeria for different construction purposes ranging from roof trusses, door frame and shutter, ceiling noggins, furniture and formwork, Isoberlinia doka and Diospyros mespiliformis have high demand for roof trusses due to their long history of durability, less insect and fungal attack. The materials for the determination of the physical and mechanical properties for the selected timber species were obtained from the following Nigerian tree species.

Table 1: The Selected Nigerian tree species.

\begin{tabular}{llll}
\hline S/No. & Trees & Local/Common names & Family \\
\hline $\mathbf{1}$ & Vitex doniana & Dinya & Verbenaceae \\
$\mathbf{2}$ & Diospyros mespiliformis & Kanya & Ebenaceae \\
$\mathbf{3}$ & Parkia biglobosa & Dorowa & Fabaceae \\
$\mathbf{4}$ & Isoberlinia doka & Doka & Caesalpinaceae \\
\hline
\end{tabular}

Timber logs sawn into $(100 \times 150 \times 1500) \mathrm{mm}$ were purchased from Zaria timber Sawmills, Kaduna state and were taken to Civil Engineering laboratory, Ahmadu Bello University (ABU) Zaria, Kaduna. There, specimens for the determination of physical and mechanical properties were prepared as specified by [8].

\subsection{Determination of physical properties \\ i. Moisture content determination}

The moisture content (MC) was determined according to [8] specification, with the use of a digital weighing balance and an electric oven in the department. The samples were initially weighed $\left(\mathbf{M}_{1}\right)$ and were kept in 
the oven at a temperature of $103 \pm 2^{\circ} \mathrm{C}$ and were reweighed $\left(\mathrm{M}_{2}\right)$. This process of weighing was repeated until constant weight was attained. The moisture content was taken as the loss in weight expressed as a percentage of the final oven-dry weight using equation 1 . The value of moisture content for each test carried out was recorded with its results.

Moisture content $=\frac{M_{1}}{M_{2}} \times 100 \%$

$\mathrm{M}_{1}=$ Initial mass (mass of timber and moisture content) that is mass before oven dried

$\mathrm{M}_{2}=$ Final mass (mass of timber alone and zero moisture) that is mass after oven dried.

\section{ii. Density determination}

The mass per unit volume of wood at a specified value of moisture content is referred to as its density, which is measured in kilogram per cubic metre. The density of wood varies with changes in moisture content. Density is often expressed at $12 \%$ moisture content. The mean density was calculated using equation 2 .

$$
p=\frac{\mathrm{M}}{\mathrm{V}}
$$

Where, $\mathrm{M}=$ the mass of the specimen, and $\mathrm{V}=$ volume of the specimen $(\mathrm{V}=1 \times \mathrm{b} \times \mathrm{h}), \mathrm{l}=$ length of the sample, $\mathrm{b}=$ breadth and $h=$ depth of the sample.

\subsection{Determination of Flexural (static bending) properties}

Flexural test is used to define the structural integrity of materials being tested.
This is measured by subjecting the material to a unified bending load. The test samples were cut into $20 \mathrm{x}$ $20 \times 300 \mathrm{~mm}$ and tested in accordance with the [8]. The three-point bending method also known as central loading method was adopted. The effective length of $280 \mathrm{~mm}$ was loaded centrally to failure.

The test pieces were free at both ends in such a way as to allow them to follow the bending action to avoid introducing longitudinal stresses as shown in the figure 1. The modulus of elasticity (MOE) and modulus of rupture (MOR) were analyzed for the strength property. The straining rate for the static bending tests was at 0.26 $\mathrm{in} / \mathrm{min}(6.6 \mathrm{~mm} / \mathrm{min})$. A total number of 40 samples were used in this test. The flexural strength was calculated using equation 3, while the Modulus of elasticity (MOE) was computed using equation 4 .

Modulus of Rupture $=\frac{3 \mathrm{~Pa}}{2 \mathrm{bd}^{2}}\left(\mathrm{~N} / \mathrm{mm}^{2}\right)$

Where $\mathrm{P}=$ Maximum Load in Kilo Newton $(\mathrm{kN})$, $\mathrm{a}=$ distance between load and the nearest support $(\mathrm{mm})$, $\mathrm{b}=$ width of cross-section $(\mathrm{mm})$

$\mathrm{d}=$ depth of cross-section $(\mathrm{mm})$

Modulus of Elasticity $=\frac{P L^{3}}{4 \Delta b d^{3}}\left(\mathrm{~N} / \mathrm{mm}^{2}\right)$

Where $\mathrm{P}=$ load in $\mathrm{N}$ at the limit of proportionality,

$\mathrm{L}=$ span of the test specimen in $\mathrm{mm}$,

$\mathrm{d}=$ depth of the test specimen in $\mathrm{mm}$,

$\mathrm{b}=$ width of the test specimen in $\mathrm{mm}$,

$\Delta=$ deflection at the limit of proportionality in $\mathrm{mm}$.

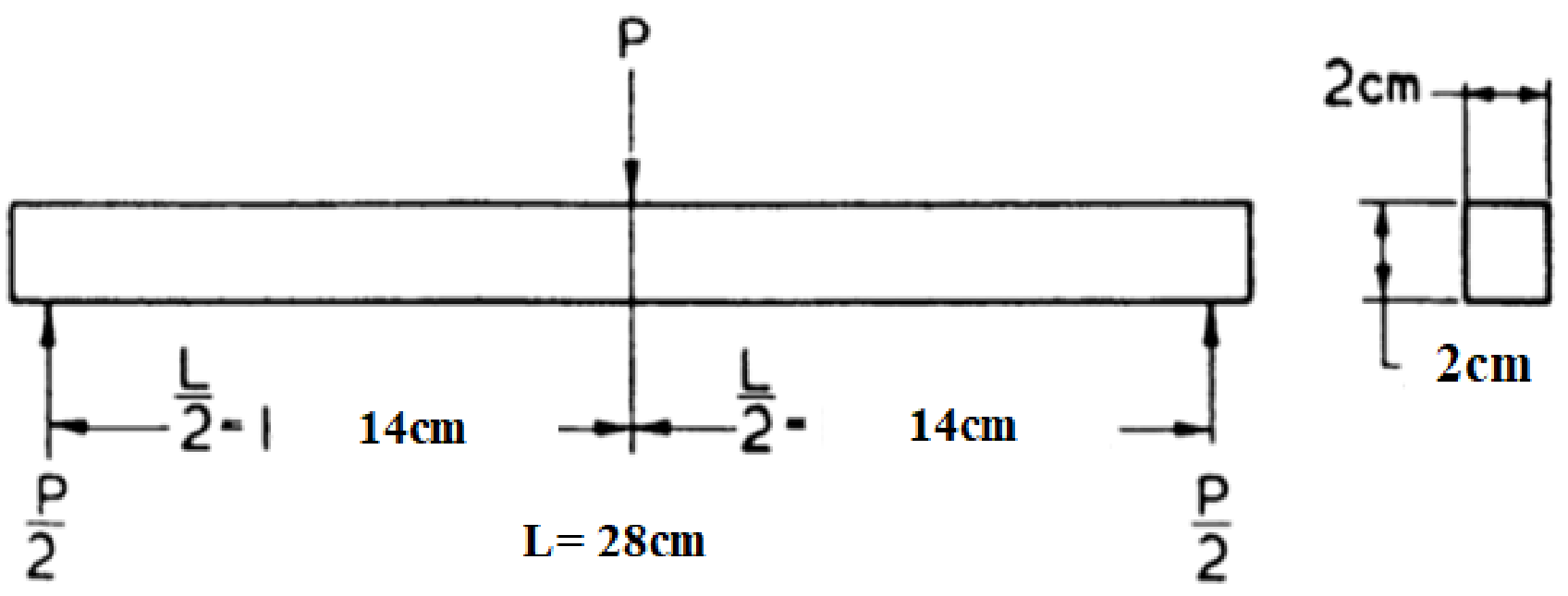

Figure 1: Sample sketch for bending parallel to the grain test. (Source: [8])

\subsection{Adjustment of Modulus of Rupture to 12\% and $18 \%$ moisture content}

The timber properties vary with variation in moisture content below fibre saturation point. For any meaningful comparison to be made, it is necessary to adjust strength values obtained at different moisture content [9].

The moduli of rupture were adjusted to $12 \%$ reference moisture using equation 5 , and this moisture content was used to determine the values of the strength 
classes. The moduli of rupture at $18 \%$ moisture content were obtained using equation 6 .

$F_{12}=F_{w}(1+\alpha(W-12)$

Where: $\mathrm{F}_{12}=$ the modulus of rupture at $12 \%$ moisture content, $\mathrm{W}=$ the moisture content at the time of testing,

$\mathrm{F}_{\mathrm{w}}=$ the modulus of rupture at the moisture content at the time of testing, $\alpha=$ the correction factor for moisture content. $\alpha$ was adapted from [10] as 0.04 .

$$
\mathrm{F}_{18 \%}=\frac{F_{12} \% \times 18}{12}
$$

\subsection{Modulus of Elasticity at $12 \%$ Moisture content}

Moduli of elasticity at experimental moisture content were adjusted to values at $12 \%$ moisture content in conformity with [11]. The adjustments were computed using equation (7) and the adjusted values are tabulated in Table 2.

$$
E_{m 12}=\frac{E_{\text {measured }}}{1+0.0143(12-u)}
$$

Where, $E_{\text {measured }}=$ the modulus of elasticity at experimental moisture content content

$\mathrm{E}_{\mathrm{m} 12}=$ modulus of elasticity at $12 \%$ moisture

$u=$ experimental moisture content.

Minimum modulus of elasticity is determined with Equation 8 showing the relationship of mean modulus of elasticity $E_{\text {mean }}$ and the minimum modulus of elasticity.

$$
E_{\text {minimum }}=E_{\text {mean }} \cdot \frac{2.33 a}{\sqrt{N}}
$$

Where, $\mathrm{N}$ is the number of samples, $\sigma$ is the standard deviation

\subsection{Density at $12 \%$ Moisture content}

The densities computed from tests results in $\mathrm{kg} / \mathrm{m}^{3}$ were adjusted to value at $12 \%$ moisture content in accordance with [11]. Equation (2.9) was used for the adjustment.

$$
p_{12}=p_{w}\left[1-\frac{(1-0.5)(u-12)}{100}\right]
$$

Where $p_{12}$ is density at $12 \%$ moisture content in $\mathrm{kg} / \mathrm{m}^{3}$, $p_{w}=$ density at experimental moisture content $\mathrm{w}=$ experimental moisture content in $\%$

\subsection{Basic and Grade Stresses}

Basic stresses for bending, compression (parallel and perpendicular to grain), tensile and shear parallel to grain were computed from failure stresses using equation (2.10). Grade stresses at $80 \%$ was equally calculated in accordance with [11].

$$
f_{b}=\frac{f_{m}-K_{p} \sigma}{K_{r}}
$$

Where $\mathrm{f}_{\mathrm{b}}=$ basic stress, $\mathrm{f}_{\mathrm{m}}=$ mean failure stresses at $12 \%$ moisture content,

$\sigma=$ standard deviation of the failure stress,

$\mathrm{K}_{\mathrm{r}}=$ reduction factor and

$\mathrm{K}_{\mathrm{p}}=$ modification factor.

The grade stresses for the species were determined for $80 \%$ using the basic stress from equation (11).

$$
f_{g b}=f_{b} \times 80 \%
$$

\subsection{Analysis of Variance (ANOVA)}

Analysis of variance (ANOVA) was used to check if there exist significant difference between the species with the help of data analysis tool pack in Microsoft excel 2019.

\section{RESULTS AND DISCUSSION}

Table 2 shows the physical and mechanical properties of these species. The mean failure, basic and grade stresses as well as $80 \%$ grade stresses are shown in Table 3.2. Moisture content and density of timber species were the physical properties considered, while the mechanical properties determined were Static Bending (MOR) and Modulus of Elasticity (MOE), Compression Parallel to Grain, Compression Perpendicular to Grain, Shear Parallel to Grain and Tension Parallel to Grain.

\subsection{Physical properties}

Table 2 shows the minimum, maximum and average values of the physical properties of the species. The moisture content results range from $8.73 \%$ to $20.21 \%$ and are below the fibre saturation level of $30 \%$. As observed by [12] increasing the moisture content of timber from zero to fibre saturation point (about 30\%), reduces the strength including the long term strength. The density obtained ranges from $492.97 \mathrm{~kg} / \mathrm{m}^{3}$ to $651 \mathrm{~kg} / \mathrm{m}^{3}$ at the natural moisture content.

\subsection{Mechanical properties}

From Table 2, apart from higher density value, Diospyros mespiliformis also has higher modulus of rupture value when compared with other species, signifying that this specie possesses high strength before rupture. It can sustain higher load before it breaks. This property is evident in the use of this specie for furniture purposes. It also has higher compression parallel to the grain. Vitex doniana showing higher resistance to shear. 
Table 2: Results of physical and mechanical properties of the selected timber species

\begin{tabular}{|c|c|c|c|c|c|c|c|c|c|}
\hline 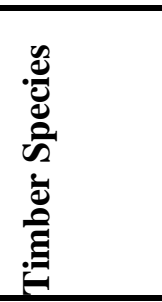 & 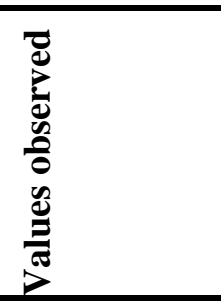 & 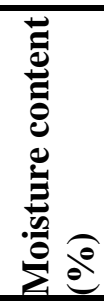 & 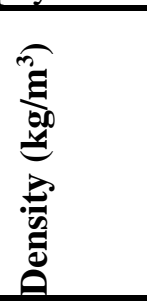 & 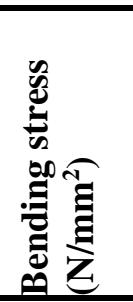 & 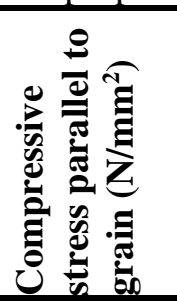 & 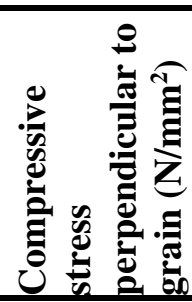 & 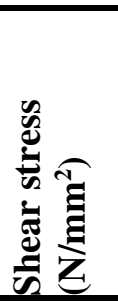 & 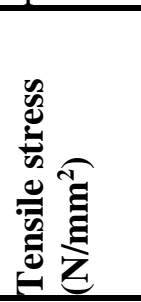 & 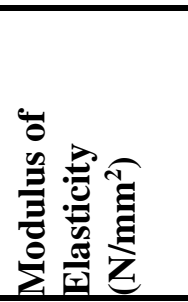 \\
\hline Dinya & Min. & 7.61 & 437.50 & 69.56 & 39.25 & 12.11 & 5.68 & 16.38 & $11,581.82$ \\
\hline (Vitex & Max. & 17.42 & 537.50 & 86.63 & 48.00 & 13.69 & 8.30 & 20.25 & $13,754.39$ \\
\hline \multirow[t]{2}{*}{ doniana) } & Average & 11.33 & 494.69 & 77.96 & 43.60 & 12.80 & 7.01 & 19.01 & $12,656.83$ \\
\hline & Std deviation & 4.68 & 36.84 & 6.98 & 3.60 & 0.71 & 1.11 & 1.76 & $1,143.90$ \\
\hline \multirow[t]{4}{*}{ Kanya } & Min. & 10.11 & 540.00 & 82.43 & 51.25 & 20.56 & 4.98 & 16.93 & $10,257.33$ \\
\hline & Max. & 19.80 & 733.75 & 93.71 & 53.88 & 22.83 & 6.78 & 19.63 & $12,061.54$ \\
\hline & Average & 15.54 & 651.00 & 86.94 & 52.23 & 21.94 & 5.67 & 18.04 & $11,220.75$ \\
\hline & Std deviation & 4.54 & 80.29 & 4.79 & 2.18 & 1.04 & 0.81 & 1.14 & 865.50 \\
\hline \multirow[t]{4}{*}{ Dorowa } & Min. & 12.01 & 393.75 & 68.25 & 34.28 & 20.62 & 4.60 & 15.63 & $13,553.19$ \\
\hline & Max. & 22.22 & 581.25 & 70.88 & 41.93 & 23.08 & 5.73 & 22.30 & $14,155.56$ \\
\hline & Average & 20.21 & 492.97 & 70.09 & 37.69 & 21.29 & 4.90 & 18.01 & $13,857.85$ \\
\hline & Std deviation & 5.82 & 73.13 & 1.26 & 3.15 & 1.15 & 0.49 & 3.26 & 272.09 \\
\hline \multirow[t]{4}{*}{ Doka } & Min. & 6.30 & 556.25 & 70.88 & 51.75 & 28.04 & 4.73 & 13.00 & $10,007.04$ \\
\hline & Max. & 11.94 & 650.00 & 81.38 & 55.00 & 30.93 & 6.78 & 16.75 & $11,854.84$ \\
\hline & Average & 8.73 & 600.25 & 76.13 & 50.75 & 29.58 & 5.71 & 15.35 & $10,706.69$ \\
\hline & Std deviation & 2.39 & 38.18 & 4.29 & 1.33 & 1.31 & 0.95 & 1.60 & 858.17 \\
\hline
\end{tabular}

Table 3: Results of mean failure, basic and grade stresses of the selected timber species

\begin{tabular}{|c|c|c|c|c|c|c|c|}
\hline 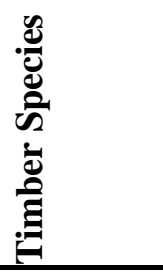 & 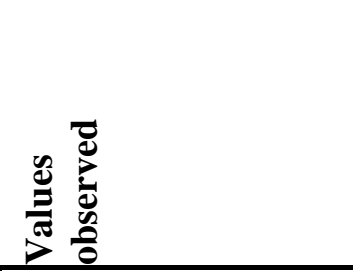 & 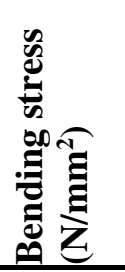 & 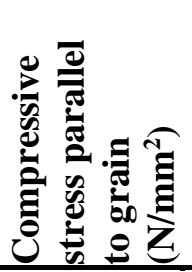 & 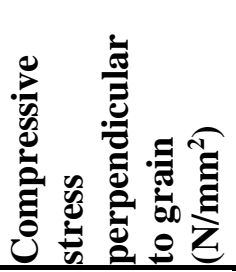 & 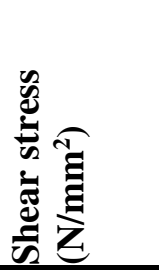 & 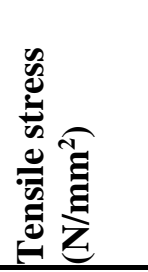 & 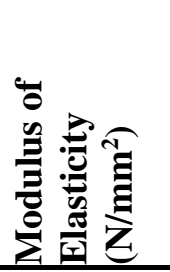 \\
\hline Dinya & Mean failure stress & 77.96 & 43.60 & 12.80 & 7.01 & 19.01 & $12,656.83$ \\
\hline (Vitex & Standard deviation & 6.98 & 3.60 & 0.71 & 1.11 & 1.76 & $1,143.90$ \\
\hline \multirow[t]{4}{*}{ doniana) } & Strength @ 12\% MC & 75.89 & 42.15 & 12.38 & 6.87 & 18.38 & $12,537.42$ \\
\hline & Strength @ 18\% MC & 57.17 & 29.07 & 8.54 & 5.60 & 12.67 & $11,555.33$ \\
\hline & Basic grade stress & 26.50 & 24.11 & 8.93 & 1.90 & 6.34 & $12,537.42$ \\
\hline & $80 \%$ Grade stress & 21.20 & 19.29 & 7.15 & 1.52 & 5.07 & $10,029.94$ \\
\hline \multirow[t]{6}{*}{ Kanya } & Mean failure stress & 86.94 & 52.23 & 21.94 & 5.67 & 18.04 & $11,220.75$ \\
\hline & Standard deviation & 4.79 & 2.18 & 1.04 & 0.81 & 1.14 & 865.50 \\
\hline & Strength @ 12\% MC & 99.24 & 61.46 & 25.82 & 6.27 & 21.23 & $11,818.70$ \\
\hline & Strength @ 18\% MC & 78.38 & 45.80 & 19.24 & 5.25 & 15.82 & $10,839.14$ \\
\hline & Basic grade stress & 39.14 & 42.01 & 19.50 & 1.94 & 8.25 & $11,818.70$ \\
\hline & $80 \%$ Grade stress & 31.31 & 33.61 & 15.60 & 1.55 & 6.60 & $9,454.96$ \\
\hline \multirow[t]{6}{*}{ Dorowa } & Mean failure stress & 70.09 & 37.69 & 21.29 & 4.90 & 18.01 & $13,857.85$ \\
\hline & Standard deviation & 1.26 & 3.15 & 1.15 & 0.49 & 3.26 & 272.09 \\
\hline & Strength @ 12\% MC & 93.10 & 53.16 & 30.03 & 6.10 & 25.40 & $15,701.22$ \\
\hline & Strength @ 18\% MC & 76.28 & 41.85 & 23.65 & 5.22 & 20.00 & $14,310.09$ \\
\hline & Basic grade stress & 40.08 & 32.73 & 22.80 & 2.21 & 7.92 & $15,701.22$ \\
\hline & $80 \%$ Grade stress & 32.06 & 26.19 & 18.24 & 1.77 & 6.33 & $12,560.98$ \\
\hline \multirow[t]{6}{*}{ Doka } & Mean failure stress & 76.13 & 50.75 & 29.58 & 5.71 & 15.35 & $10,706.69$ \\
\hline & Standard deviation & 4.29 & 1.33 & 1.31 & 0.95 & 1.60 & 858.17 \\
\hline & Strength @ 12\% MC & 66.18 & 42.46 & 24.75 & 5.15 & 12.84 & $10,228.96$ \\
\hline & Strength @ 18\% MC & 47.91 & 27.24 & 15.88 & 4.12 & 8.24 & $9,454.00$ \\
\hline & Basic grade stress & 24.97 & 28.12 & 18.07 & 1.30 & 4.05 & $10,228.96$ \\
\hline & $80 \%$ Grade stress & 19.98 & 22.50 & 14.46 & 1.04 & 3.24 & $8,183.17$ \\
\hline
\end{tabular}




\subsection{Analysis of Variance}

The ANOVA test result on moisture content is presented in Table 3.3. The F-statistic and P-value for moisture content between the species were 4.9274 and 0.013 , respectively. With the F-statistic greater than the critical value $\left(\mathrm{F}_{\text {crit }}=3.2389\right)$ signifies the existence of difference in moisture content within the four selected timber species. This could be attributed to the characteristics of the location from which they were obtained.

Table 4: Summary of ANOVA for Moisture content determination

\begin{tabular}{|c|c|c|c|c|c|c|}
\hline Timber Species & & Count & Sum & Average & Variance & \\
\hline Dinya & & 5 & 58.05 & 11.61 & 16.634 & \\
\hline Kanya & & 5 & 76.17 & 15.23 & 16.115 & \\
\hline Dorowa & & 5 & 89.57 & 17.91 & 28.843 & \\
\hline Doka & & 5 & 43.67 & 8.73 & 4.314 & \\
\hline $\begin{array}{l}\text { Source of } \\
\text { variation }\end{array}$ & SS & df & MS & $\mathbf{F}$ & P-value & $\mathbf{F}_{\text {crit }}$ \\
\hline Between Groups & 243.5625 & 3 & 81.1875 & 4.9274 & 0.0130 & 3.2389 \\
\hline Within Groups & 263.6288 & 16 & 16.4768 & & & \\
\hline Total & 507.1912 & 19 & & & & \\
\hline
\end{tabular}

The timber cell cavity and cell wall are a function of its density. From the ANOVA results obtained in Table 3.4, the F-statistic obtained for the density between the species is greater than the critical value $\left(8.5148>\mathrm{F}_{\text {crit }}\right)$. This signifies that there is variability in density of the species.

Table 5: Summary of ANOVA for Density determination

\begin{tabular}{|c|c|c|c|c|c|c|}
\hline Timber Species & & Count & Sum & Average & Variance & \\
\hline Dinya & & 5.00 & 2473.47 & 494.69 & 1357 & \\
\hline Kanya & & 5.00 & 3255.00 & 651.00 & 6446 & \\
\hline Dorowa & & 5.00 & 2464.87 & 492.97 & 5348 & \\
\hline Doka & & 5.00 & 3001.25 & 600.25 & 1457.34 & \\
\hline $\begin{array}{l}\text { Source of } \\
\text { variation }\end{array}$ & SS & df & MS & $\mathbf{F}$ & P-value & $\mathbf{F}_{\text {crit }}$ \\
\hline Between Groups & 93290.409 & 3 & 31096.803 & 8.5148 & 0.0013 & 3.2389 \\
\hline Within Groups & 58433.554 & 16 & 3652.097 & & & \\
\hline Total & 151723.963 & 19 & & & & \\
\hline
\end{tabular}

\subsection{Regression Analysis}

Table 3.5 presents the coefficient of determination, $\mathrm{R}^{2}$ at $95 \%$ confidence level for density ranges from $2.7 \%$ to $34 \%$ with Modulus of rupture showing a weak relationship with density $\left(\mathrm{R}^{2}<5 \%\right)$. Other strength properties could be well modelled statistically with density $\left(\mathrm{R}^{2}>5 \%\right)$ using regression analysis.

Table 6: Regression between Density and Strength

\begin{tabular}{lll}
\hline Strength Properties & Regression Equations & $\mathbf{R}^{\mathbf{2}(\%)}$ \\
\hline MOR & $\mathrm{Y}=0.03157 \mathrm{x}+65.9280$ & 0.027 \\
MOE & $\mathrm{Y}=18.37078 \mathrm{x}-2508.1642$ & 0.340 \\
Compression parallel & $\mathrm{Y}=0.05576 \mathrm{x}+18.59629$ & 0.223 \\
Compression parallel & $\mathrm{Y}=-0.08279 \mathrm{x}+77.43177$ & 0.096 \\
Shear parallel & $\mathrm{Y}=-0.00393 \mathrm{x}+8.29272$ & 0.189 \\
Tension parallel & $\mathrm{Y}=-0.02320 \mathrm{x}+32.44982$ & 0.120 \\
\hline
\end{tabular}


Table 7: Regression between Density and Strength

\begin{tabular}{lll}
\hline Strength Properties & Regression Equations & $\mathbf{R}^{2}(\%)$ \\
\hline MOR & $\mathrm{Y}=2.57898 \mathrm{x}+47.61626$ & 0.722 \\
MOE & 0.050 & \\
Compression parallel & $\mathrm{Y}=1.29167 \mathrm{x}+31.78510$ & 0.487 \\
Compression parallel & $\mathrm{Y}=3.47761 \mathrm{x}+-17.43639$ & 0.685 \\
Shear parallel & $\mathrm{Y}=0.04280 \mathrm{x}+5.49722$ & 0.091 \\
Tension parallel & $\mathrm{Y}=1.02145 \mathrm{x}+5.20938$ & 0.947 \\
\hline
\end{tabular}

The coefficient of determination $\left(\mathrm{R}^{2}\right)$ at $95 \%$ confidence level for moisture content ranges from $5 \%$ to 94.7\%. All the strength properties show a strong relationship with moisture content and hence could be well modelled statistically with moisture content using regression.
Strength and stiffness properties perpendicular to grains are much lower than along the grains, except for Parkia biglobosa which has approximately 15\% strength greater than in the perpendicular direction. Generally, timbers are weak in shear when compared with other strength properties.

Table 8: Summary of strength properties at $12 \%$ moisture content

\begin{tabular}{lllllll}
\hline Timber & MOE & MOR & $\begin{array}{l}\text { Compression } \\
\text { parallel }\end{array}$ & $\begin{array}{l}\text { Compression } \\
\text { perpendicular }\end{array}$ & $\begin{array}{l}\text { Shear } \\
\text { parallel }\end{array}$ & $\begin{array}{l}\text { Tension } \\
\text { parallel }\end{array}$ \\
\hline & $\left(\mathrm{N} / \mathrm{mm}^{2}\right)$ & $\left(\mathrm{N} / \mathrm{mm}^{2}\right)$ & $\left(\mathrm{N} / \mathrm{mm}^{2}\right)$ & $\left(\mathrm{N} / \mathrm{mm}^{2}\right)$ & $\left(\mathrm{N} / \mathrm{mm}^{2}\right)$ & $\left(\mathrm{N} / \mathrm{mm}^{2}\right)$ \\
'Dinya' & $12,537.42$ & 75.89 & 42.15 & 12.38 & 6.87 & 18.38 \\
'Kanya' & $11,818.70$ & 99.24 & 61.46 & 25.82 & 6.27 & 21.23 \\
'Dorowa' & $15,701.22$ & 93.10 & 53.16 & 61.41 & 6.10 & 25.40 \\
'Doka' & $10,228.96$ & 66.18 & 42.46 & 24.75 & 5.15 & 12.84 \\
\hline
\end{tabular}

\subsection{Classification and Grading of the Timber species \\ Table 8 summarizes the results of this} experimental-based research. The four species were classified and graded in accordance with the [11] and the [13]. The criteria for this classification and grading are summarized in Table 7.

Table 9: Classification and grading criteria

According to BS 5268 (2002)
If the characteristic value of grade bending stress and
mean density are greater than or equal to values on
Table 8 , BS 5268-2 (20002) and the mean modulus of
elasticity in bending equal or greater than $95 \%$ of the
value given in that strength class giving in Table 8 of
BS 5268-2 (2002)
According to (NCP 2).

If the strength value obtained is equal to or greater than the value on Table 7, NCP 2 (1973) for a given dry basic stress, such belongs to that class.

Table 10: Strength Classification of the Selected Timber Species

\begin{tabular}{lllllll}
\hline Timber & $\begin{array}{l}\mathbf{8 0 \%} \text { Grade Bending } \\
\text { stress }\left(\mathbf{N} / \mathbf{m m}^{2}\right)\end{array}$ & $\begin{array}{l}\text { Modulus of } \\
\text { Elasticity } \\
\left(\mathbf{N} / \mathbf{m m}^{\mathbf{2}}\right)\end{array}$ & $\begin{array}{l}\text { Density } \\
\left(\mathbf{k g} / \mathbf{m}^{3}\right)\end{array}$ & $\begin{array}{l}\text { Characteristic } \\
\text { density }\left(\mathbf{k g} / \mathbf{m}^{\mathbf{3}}\right)\end{array}$ & $\begin{array}{l}\text { BS 5268-2 } \\
(\mathbf{2 0 0 2})\end{array}$ & $\begin{array}{l}\text { NCP 2 } \\
(\mathbf{1 9 7 3})\end{array}$ \\
\hline Dinya & 21.20 & 12,537 & 494.69 & 496 & $\mathrm{D} 30$ & $\mathrm{~N} 4$ \\
Kanya & 31.31 & 11,819 & 651.00 & 640 & $\mathrm{D} 40$ & $\mathrm{~N} 3$ \\
Dorowa & 32.06 & 15,701 & 492.97 & 478 & $\mathrm{C} 40$ & $\mathrm{~N} 4$ \\
Doka & 19.98 & 10,229 & 600.25 & 610 & $\mathrm{D} 30$ & $\mathrm{~N} 3$ \\
\hline
\end{tabular}




\subsection{CONCLUSION AND RECOMMENDATION}

Laboratory experiments were conducted on the four selected timber species; Vitex doniana (Dinya), Diospyros mespiliformis (Kanya), Parkia biglobosa (Dorowa) and Isoberlinia doka (Doka) and tested according to BS 373:57. From the results, the physical and mechanical properties were established and the variation in these properties among the species was shown by subjecting the results obtained to ANOVA test and Regression Analysis. These four timber species were successfully characterized and graded according to BS 5268 (2002) and NCP 2 (1973). The characterized and graded selected timber species can be utilized for both structural and non-structural applications. Other less utilized grown trees in this part of the country can be explored for characterization and grading to be used in the building and construction industries, as this will help to reduce over-exploitation of the few commercial species such as Mahogany, Obeche and Teak whose properties are well known.

\section{REFERENCES}

[1] Ross, P. "Appraisal and repair of timber structures". Structural Engineer, 80(17), (2002) 26. https://doi.org/10.1680/arts.61781

[2] Aguwa, J. I., Chukwu, P. C. and Auta, S. M. "Characterization and grading of South Eastern Nigeria grown Irvingia gabonensis timber in accordance with BS 5268. USEP:" Journal of Research Information in Civil Engineering, 12(2), (2015), 720-731.

[3] Jacobs, M. H. "Introduction to Aluminium as an Engineering Material Introduction to Aluminium as an Engineering Material". TALAT. Basic Level, 1201, 1-9, (1999).

[4] ObinnaOsuji, S. and Inerhunwa, I. "Characterization and Strength Classification of Timber Species in Akwa Ibom State, Nigeria for Structural
Engineering Applications." International Journal of Engineering Research and Applications (IJERA), 7(103), (2017), 2248-962201.

[6] Kaura, J. M., I. Abubakar, and Aliyu. I. "EN 338 Strength grade and uncertainty models of material properties for Nigerian Grown Terminalia superba (White Afara) timber specie." Nigerian Journal of Technology 34(1), (2015), 21-27. https://doi.org/10.4314/njt.v34i1.3

[7] Idris, A. and Muhammad, N.A. "Development of EN338 (2009) strength classes for some common Nigerian timber species using three point bending test." International Journal of Civil and Environmental Engineering, 7(5), (2013), 338-342.

[8] British Standards 373. "Method of Testing Small Clear Specimens of Timber". British Standard Institute, London, (1957).

[9] Ishengoma, R. C. and Nagoda, L. "Solid Wood: Physical and mechanical properties, defects, grading and utilisation as fuel". Morogoro: A teaching compendium, Sokoine University of Agriculture, (1991).

[10] Zziwa, A., Ziraba, Y.N. and Mwakali, J.A. "Strength properties of selected Uganda Timbers". International Wood Products Journal, 1(1), (2010), $21-27$.

[11] British Standards 5268. "Structural use of timber Part 2: Code of practice for permissible stress design, materials and workmanship". British Standard, 2(1), (2002), 1-184.

[12] Aguwa, J. I. The Nigerian Timber Structures. Ahmadu Bello University Press Ltd, (2016).

[13] NCP2. Nigerian Standard Code of Practice: The use of timber for costruction. Lagos, Nigeria: Standard Organisation of Nigeria, Federal Ministry of Industries, (1973). 